\title{
Impact of Community Based Fish Culture on Seasonal Floodplain Beel - A Comparative Study
}

\author{
M. I. Hossain ${ }^{1 *}$, C. Siwar ${ }^{1}$, M. B. Mokhtar ${ }^{1}$, M. M. Dey ${ }^{2}$, and A. H. Jaafar ${ }^{2}$ \\ Institute for Environment and Development (LESTARI), Universiti Kebangsaan Malaysia \\ 43600 UKM BANGI, Selangor Darul Ehsan, Malaysia \\ ${ }^{2}$ Aquaculture Economics and Marketing, Aquaculture/Fisheries Center, University of Arkansas Pine \\ Bluff, USA \\ ${ }^{3}$ Graduate Program Coordinator, Faculty of Business, Universiti Kebangsaan Malaysia
}

Received 17 September 2009, accepted in final revised form 20 March 2010

\begin{abstract}
Beel Mail is a 100 ha seasonal floodplain beel where community based fish culture was introduced during rainy season with 73 community members by department of fisheries with the funding support of WorldFish Center in year 2006. Socio-economic impact of this management was compared with control beel Chandpur. Beel Chandpur is 200 ha seasonal floodplain beel where also 16 landowner part time fishermen introduced fish culture during flooding. Beel Mail was stocked with $34.93 \mathrm{~kg} \mathrm{ha}^{-1}$ fish fingerlings and beel Chandpur was stocked with $9.68 \mathrm{~kg} \mathrm{ha}^{-1}$. Fish was harvested after about 6 months culture period and it was noticed that the gross production was about 4.7 times higher in the project site than the control site. Farmers obtained TK $7481.23 \mathrm{ha}^{-1}$ as net return based on production cost in beel Mail and TK $3261.90 \mathrm{ha}^{-1}$ as net return based on production cost in beel Chandpur. Average fish consumption increased by $20.49 \%$ in project site. In addition, future stocking and saving fund for fishermen society were established and sharing of benefit from fish culture was more evenly distributed between landowners and landless fishermen in project site than control beel.
\end{abstract}

Keywords: Beel; Landowner; Landless; Community based fisheries management.

(c) 2010 JSR Publications. ISSN: 2070-0237 (Print); 2070-0245 (Online). All rights reserved.

DOI: 10.3329/jsr.v2i2.3430 J. Sci. Res. 2 (2), 369-379 (2010)

\section{Introduction}

Growing awareness has been observed around the world since the 1980s on management of common property resources including fisheries. Focus of these studies was on community based fisheries management (CBFM) and co-management in contrast to traditional management systems in existing property rights of the open waterbodies. CBFM has become a common strategy for managing open waterbodies and for empowering local communities by involving community stakeholders, recognizing local

\footnotetext{
*Corresponding author: bitanrubd@yahoo.com
} 
needs, using local knowledge and establishing common property regimen [1-3]. Because of implementing various types of policies and initiatives by the government of Bangladesh in the past, there exists a range of property rights in fisheries, including state or government ownership of all fisheries, open access in rivers, traditional common property in floodplains, private ownership under leasing arrangements, and community access through leases and licensing. Concepts of common as open access resources has been identified as major reason of over exploitation of fisheries resources and has been described as "tragedy of the commons" [4] A new perception of common has been given by Bromley and Cornea [5], and Berkes [6] as the property right regimes where the users jointly own the resource and are subject to rules and practices set by that community of users.

In the seasonally flooded rice fields farmers grow high yielding irrigated rice crop during dry season. But farmers abandoned deep water rice and let the land lie fallow after the irrigated rice had been harvested because there was no time before the rains began to establish the deep water rice. The reason for conducting this study was to assess the feasibility of community based fish culture in seasonal floodplain beel. And also to establish an agricultural activity in this fallow land which is accepted by crop and fish stakeholder. This study reports on successful implementation of CBFM in seasonal floodplain beel (beel Mail of Rajshahi district, Bangladesh) in the year 2006. In 2005, stocking of Carp fingerlings were practiced by a group of landowners of that beel. But the production level and income was not satisfactory. This study demonstrates the potential of managing seasonal water bodies by community involvement which is economically more profitable and also more acceptable than the group approach in managing these aquatic ecosystems.

The seasonal floodplain beel Mail is situated in Mohanpur town of Rajshahi district, Bangladesh. It is open waterbody connected nearby a local Shiba River, which further connected to Padma river basin. The area of this beel is 100 ha in which 85 ha is under the private owner and rest is under the government. Average water depth was 0.08 to 1.51 meter having inundated during July to November in monsoon. The average water temperature, $\mathrm{pH}$ and dissolved oxygen were $29 \pm 1.60{ }^{\circ} \mathrm{C}, 7.71 \pm 0.17$ and $5.56 \pm 0.19$ mg/liter respectively. Melandi, Goalpara, Dangapara and Moheskundi villagers are the main beneficiaries of this beel. The community based fish culture was intervened by the Department of fisheries (DoF), Bangladesh, with the funding support of Challenge program for water and food project, south-east Asia, WorldFish center. To compare the study results of project beel, one control beel was selected with same agro-ecological (agriculture farm, fish culture, natural environment) environment.

The control beel Chandpur is situated at the village of Batupara, Mohanpur Upazila, Rajshahi is mainly private lands with total 202.43 ha of which 9.15 ha is under the government. Average water depth was 1.09 to 1.75 meter during July to November in wet season and water temperature, $\mathrm{pH}$ and dissolve oxygen were $29 \pm 1.54{ }^{\circ} \mathrm{C}, 7.72 \pm 0.15$ and $5.58 \pm 0.22 \mathrm{mg} /$ liter, respectively This beel is connected with Barnoi River, which further connected to Padma basin. There are 5 villages surrounding the beel area namely Batupara, 
Horiphala, Chandpur, Chuniapara and Nondonhut are the beneficiaries. In this beel a group of landowners are involved in fish culture during monsoon.

Impact of community based fish culture in seasonally flooded aquatic resources has been assessed by comparing the total farm income from fish, fish consumption between landowners and landless in the project site with that of control site and also with other activities that will enhance fish culture in these flooded beels in the following years.

\section{Social Mobilization and Community Formation for CBFM in Beel Mail}

In 2006, beel Mail was selected for introducing CBFM project by Department of Fisheries, Bangladesh (DoF) with the funding support of WorldFish Center. After arranging several group discussions with the village leaders, different stakeholders, landowners, landless fishermen, government officers and WorldFish Center stauffs, a community of 73 members was formed to introduce fish culture in beel Mail. Among the community members, 21 persons were landowners who provide money to the landless fishermen (registered by government as local fishermen society) for leasing the beel in wet season. Community members attended training on fisheries management, stocking, harvesting, accounts, saving schemes etc to develop their skill.

\section{Stocking of Fish Fingerlings}

During flooding in wet season small indigenous fish species come with the flood water by different channel in both project and control beel. These fishes were known as non stocked fish. Stocked fishes were stocked with those of non stocked fishes during stocking.

In project beel Mail, $3493 \mathrm{~kg}$ (about $34.93 \mathrm{~kg} \mathrm{ha}^{-1}$ ) fish fingerlings were stocked. The number of fish fingerlings was $747 \mathrm{ha}^{-1}$. The fish species were Catla (Catla catla), Bighead (Ctenopharyngon idella), Rui (Labea rohita), Mrigal (Cirrhinus mrigala) and Carpio (Cyprinus carpio) (Table 1). Fish fingerlings were released during $22^{\text {nd }}$ to $24^{\text {th }}$ of July 2006 and harvested on 29 of March 2007.

Table 1. Stoking ratio of carp fish fingerlings and its prices in beel Mail.

\begin{tabular}{ccccccr}
\hline \multirow{2}{*}{ Species } & \multicolumn{2}{c}{ Numbers } & \multicolumn{2}{c}{ Weight (Kg) } & \multicolumn{2}{c}{ Price } \\
\cline { 2 - 7 } & Total & $\begin{array}{c}\text { Per } \\
\text { hectare }\end{array}$ & $\begin{array}{c}\text { Total } \\
(\mathrm{Kg})\end{array}$ & $\begin{array}{c}\text { Per } \\
\text { hectare }\end{array}$ & $\begin{array}{c}\text { Rate } \\
(\mathrm{TK} \mathrm{Kg} \\
1\end{array}$ & Total (TK) \\
\hline Catla & 10018 & 100 & 551 & 5.51 & 120 & 66120.00 \\
Bighead & 31980 & 320 & 1567 & 15.67 & 61.5 & 96370.00 \\
Rui & 6361 & 64 & 528 & 5.28 & 110 & 58080.00 \\
Mrigal & 10889 & 109 & 294 & 2.94 & 95 & 27930.00 \\
Carpio & 15361 & 154 & 553 & 5.53 & 74.4 & 41170.00 \\
GT & 74609 & 747 & 3493 & 34.93 & 82.9 & 289670.00 \\
\hline
\end{tabular}

Source: [8] 
At control beel Chandpur total $1960 \mathrm{~kg}$ of carp fish fingerlings (about $9.68 \mathrm{~kg} \mathrm{ha}^{-1}$ ) which was average 324.6 number per hectare released by some landowners without following any community based fish culture approach. The local and scientific name of these fish species are Catla (Catla catla), Bighead (Ctenopharyngon idella), Rui (Labea rohita), Carpio (Cyprinus carpio) and Silver carp (Hypophthalmichthyes molitrix) (Table 2). Fish fingerlings were released during $29^{\text {th }}$ June to $27^{\text {th }}$ of July, 2006 at morning session. Culture period of fishes was about 9 months as harvested on 25th March 2007.

Table 2. Stoking ratio of carp fish fingerlings and its prices in beel Chandpur.

\begin{tabular}{ccccccc}
\hline \multirow{2}{*}{ Species } & \multicolumn{2}{c}{ Numbers } & \multicolumn{2}{c}{ Weight $(\mathrm{Kg})$} & \multicolumn{2}{c}{ Price } \\
\cline { 2 - 7 } & Total & $\begin{array}{c}\text { Per } \\
\text { hectare }\end{array}$ & $\begin{array}{l}\text { Total } \\
(\mathrm{Kg})\end{array}$ & $\begin{array}{c}\text { Per } \\
\text { hectare }\end{array}$ & $\begin{array}{c}\text { Rate } \\
(\mathrm{TK} \\
\left.\mathrm{Kg}^{-1}\right)\end{array}$ & $\begin{array}{c}\text { Total } \\
(\mathrm{TK})\end{array}$ \\
\hline Catla & 9000 & 44.5 & 280 & 1.38 & 80 & 22400 \\
Bighead & 20000 & 98.8 & 600 & 2.96 & 37.5 & 22500 \\
Rui & 9000 & 44.5 & 320 & 1.58 & 67.5 & 21600 \\
Carpio & 21000 & 103.7 & 600 & 2.96 & 62.5 & 37500 \\
Silver & 6700 & 33.1 & 160 & 0.79 & 37.5 & 6000 \\
GT & 65700 & 324.6 & 1960 & 9.68 & 57 & $1,10,000$ \\
\hline
\end{tabular}

Source: [8]

Fish was harvested since $13^{\text {th }}$ of October 2006 to $29^{\text {th }}$ March 2007 in the study beel Mail whereas in control beel Chandpur fish harvesting was done from $1^{\text {st }}$ of February 2007 to $30^{\text {th }}$ of March 2007.

\section{Impact on Fish Production}

Production of non stocked fish species from per hectare waterbody in project and in control beel were $86.4 \mathrm{~kg}$ and $30.78 \mathrm{~kg}$ respectively. Gross yields of stoked fishes were $215.5 \mathrm{~kg} / \mathrm{ha}$ and $33.64 \mathrm{~kg} / \mathrm{ha}$ in beel Mail and beel Chandpur respectively. Per hectare net yields of stocked fishes were calculated by the gross yield of harvested carp yields minus weight of fingerlings stocked. Per hectare net yields of stocked fishes were $180.6 \mathrm{~kg}$ in project beel and $24 \mathrm{~kg}$ in control beel. Thus per hectare total net production of fishes were $267 \mathrm{~kg}$ and $54.8 \mathrm{~kg}$ in project beel Mail and control beel Chandpur, respectively (Table 3).

Per hectare gross returns of fishes were valued by multiplying the total amount of gross yields with the prevailing market price. Net returns of fishes were calculated by deducting the production costs from the gross return of harvested fish. The gross and net return from the two experimental sites are mentioned in Table 4. 
Table 3. Per hectare yields from fishes in seasonal flooded beels.

\begin{tabular}{lrrrr}
\hline \multirow{2}{*}{ Particulars } & \multicolumn{2}{c}{ Mail (project) } & \multicolumn{2}{c}{ Chandpur (control) } \\
\cline { 2 - 5 } & Unit (kg) & \% of total & Unit (kg) & \% of total \\
\hline Gross yields $\left(\mathrm{kg} \mathrm{ha}^{-1}\right)$ & & & & \\
Stocked fishes & 215.50 & 71.38 & 33.60 & 52.17 \\
Non-stocked fishes & 86.40 & 28.62 & 30.80 & 47.83 \\
Total & 301.90 & 100.00 & 64.40 & 100.00 \\
Net yields (kg ha $\left.{ }^{-1}\right)$ & & & & \\
Stocked fishes & 180.60 & 67.64 & 24.00 & 43.80 \\
Non-stocked fishes & 86.40 & 32.36 & 30.80 & 56.20 \\
Total & 267.00 & 100.00 & 54.80 & 100.00 \\
\hline
\end{tabular}

Source: [8]

Table 4. Per hectare returns from fishes in seasonal flooded beels.

\begin{tabular}{lcccc}
\hline \multirow{2}{*}{ Particulars } & \multicolumn{2}{c}{ Project beel Mail } & \multicolumn{2}{c}{ Control beel Chandpur } \\
\cline { 2 - 5 } & Unit (TK) & \% of total & Unit (TK) & \% of total \\
\hline Production costs (TK/ha) & 7283.17 & 100.00 & 1444.58 & 100.00 \\
Total all cost (TK/ha) & 8138.43 & 100.00 & 1616.35 & 100.00 \\
Gross return (TK/ha) & & & & \\
$\quad$ Stocked fishes & 10278.8 & 69.62 & 2497.78 & 53.07 \\
$\quad$ Non-stocked fishes & 4485.6 & 30.38 & 2208.7 & 46.93 \\
$\quad$ Total & 14764.4 & 100.00 & 4706.48 & 100.00 \\
Net return (TK/ha) & & & & \\
$\quad$ Based on production & 7481.23 & - & 3261.90 & - \\
$\quad$ Based on all costs & 6625.97 & - & 3090.13 & - \\
\hline
\end{tabular}

Source: [8]

\section{Impact on Income}

The impact of community based fish culture in seasonally flooded rice fields on the distribution of farm income among landowners and landless farmers participated in fish culture was calculated based on pre-agreed sharing arrangement of benefit obtained from fish culture between these two social groups. Results show that with the introduction of community based fish culture under the alternating fish and rice system, the annual 
household income increased by as much as $9.05 \%$ for landless farmers and $12.55 \%$ for the landowners only from fish (Table 5)

Table 5. Impact of fish culture on income in seasonally flooded rice fields of beel Mail.

\begin{tabular}{lccccc}
\hline & \multirow{2}{*}{$\begin{array}{c}\text { Baseline total } \\
\text { income } \\
\text { Tenure status }\end{array}$} & \multicolumn{3}{c}{ Income from fishes (Taka/household) } \\
\cline { 3 - 6 } & (TK/Annual & Before & After project & $\begin{array}{c}\text { Increased } \\
\text { income }\end{array}$ & $\begin{array}{c}\text { Income } \\
\text { increased (\%) }\end{array}$ \\
\hline Landless & 36407 & 4513 & 7808 & 3294 & 9.05 \\
Landowner & 96888 & 9477 & 21633 & 12156 & 12.55 \\
\hline
\end{tabular}

\section{Impact on Fish Consumption}

Food consumption of different types of households (landowners and landless) was monitored both in project and control site. Baseline consumption data was collected before intervention of community based fish culture and then to assess impact of fish culture on food consumption. This was done by collecting monthly consumption data during May, June and July and October, November and January at sites. Every seven days food consumption data in each month was collected to make an estimation of average food consumption of the household members. Results showed that in both sites, fish consumption increased due to intervention of fish culture with new approach of management. In project site average per capita fish consumption of participating landless fishermen and landowners increased by 23.70\% and 17.57\% respectively (Table 6 and Fig. 1). In control site fish consumption also increased during harvesting. Average per capita fish consumption was better by $29.75 \%$ for landless fishers and $9.09 \%$ for landowners (Table 6 and Fig. 2). It was also observed that average per capita fish consumption of landless fishermen and landowners in project site was much better than that of landless fishermen and landowners in control site.

Table 6. Fish consumption (Kg/capita/month) status of sample landowners (LO) and landless (LL) fishermen in project site and control site.

\begin{tabular}{lcccccc}
\hline \multirow{2}{*}{$\begin{array}{l}\text { Fish } \\
\text { consumption }\end{array}$} & \multicolumn{3}{c}{ Project beel Mail } & \multicolumn{3}{c}{ Control beel Chandpur } \\
\cline { 2 - 7 } & LO & LL & Average & LO & LL & Average \\
\hline Peak average & 1.9 & 1.92 & 1.91 & 1.75 & 1.84 & 1.80 \\
Lean average & 1.58 & 1.42 & 1.5 & 1.61 & 1.3 & 1.46 \\
Baseline & 1.48 & 1.35 & 1.42 & 1.54 & 1.21 & 1.38 \\
Change & 0.26 & 0.32 & 0.29 & 0.14 & 0.36 & 0.25 \\
\% of change & 17.57 & 23.70 & 20.49 & 9.09 & 29.75 & 17.75 \\
\hline
\end{tabular}

Source: [8] 
The fish consumption (kg/capita/month) status of sample landowners and landless fishermen in project site has been shown in Figs 1 and 2.

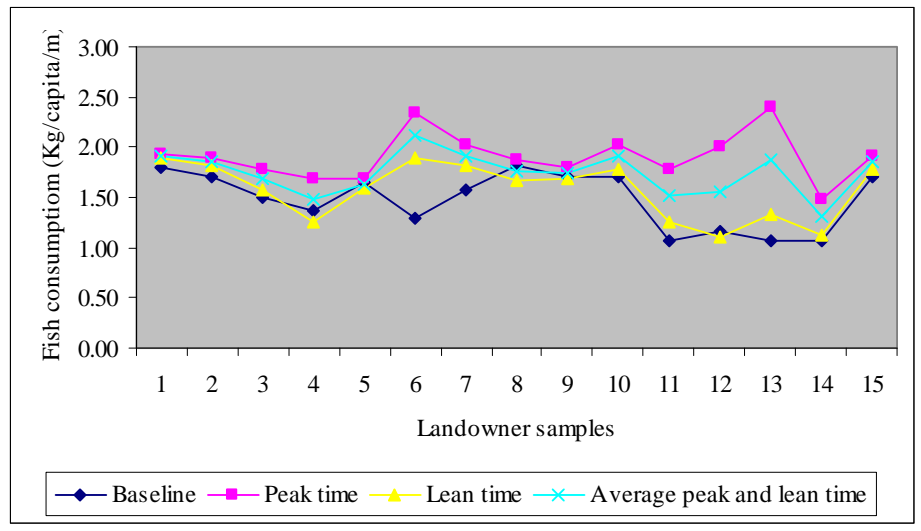

Fig. 1.

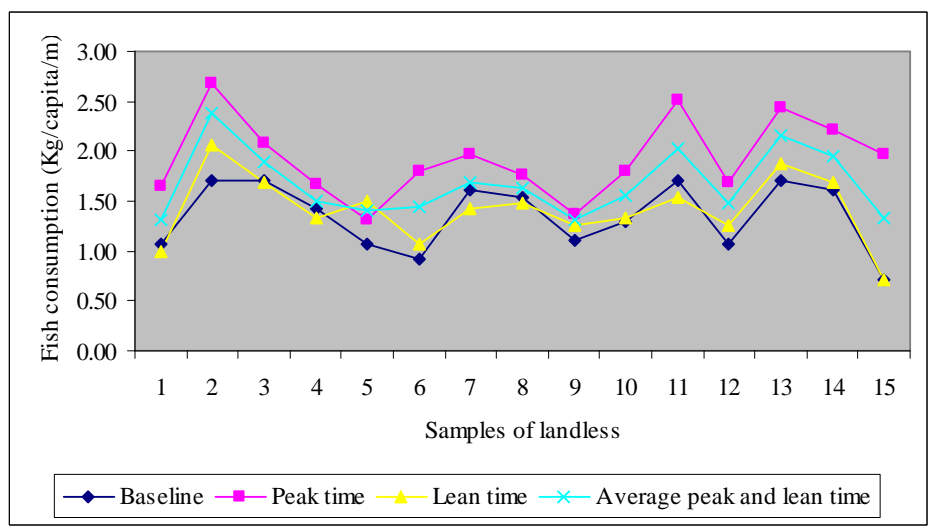

Fig. 2.

\section{Social Impact}

It is difficult to quantify the social impact of CBFM on the social groups in project site than to assess the economic impact. Five indicators are presented below, which reflect the social impact of CBFM.

\subsection{Stocking cost of fish fingerlings}

The total cost of fish fingerlings was TK 2, 89, 670 in beel Mail which was provided by the WorldFish center as donation with some agreement to the community. The community members will return the money after selling the product without any interest to a joint 
account of the Upazila fisheries Officer and the fishermen society leader. This fund will be revolved for stocking of fish fingerlings in the beel Mail in the following years. The community members earned total TK 14, 36, 572 by selling fish and refunded the money during this period.

\subsection{Sharing of benefits from fish culture}

In everyday, income by selling fish was distributed according to pre- agreed sharing arrangements among share holders. Fifty two landless fishermen got $20 \%$ from stocked fishes and $50 \%$ from non stocked fishes. In addition to this, each fish harvesting day landless fishermen received almost $0.5 \mathrm{~kg} /$ person of non-stocked fish for their family consumption. Then all expenses of fish culture were deducted from selling of remaining fish and $12.5 \%$ of net return was secured for fishermen society. Rest of the money distributed among 21 landowners of the community.

In the control site, 19 landless fishermen got 14\% of both stocked and non stocked fish as labor chargeand rest of $86 \%$ was taken by the 16 landowners.

It is observed that landless people were able to take major part of benefit by the community based fish culture approach. But in the control site most of the benefits of fish culture were obtained by landowners. Thus community based fish culture ensures sharing of benefits among social groups.

\subsection{Fund raising for the fishermen society}

By agrement, $12.5 \%$ of the net return from selling of fish will be used for raising fund for the fishermen society. Thus at the end of fish culture in the first year, TK 64,900 was saved for the fishermen society. Intention of fund raising was that, the fishermen group will contribute to lease money in the next year from this fund and thus will be able to earn more in the following years by increasing the share.

\subsection{Attitudinal changes to community based fish culture}

Both landowners and landless fishermen were inspired after intervention of community based fish culture in beel Mail. To raise their income from fish culture in this unused waterbody, it is needed to practice of new such technology in future. Under this project, fishermen received technical training regarding fish culture in open water body. To achieve maximum benefit from fish culture in this seasonal flood plain it is required to maintains the number and size of fish fingerlings release. Landowners and landless people were motivated to continue this approach in the following years and to establish a sanctuary for preserving brood fish of small indigenous fish species. Even fish farmers in the control site showed interest on receiving training on fish culture technology and to adopt the technology with financial supports. 


\subsection{Access of subsistence fishers}

In project beel, open access of subsistence fishers were restricted. But the non participating landowners were allowed to catch only small indigenous fish species (SIS) with fishing gear khulshun. In the control beel fishing access of the subsistence fishers was not restricted.

\section{Discussion}

Fish culture in seasonal floodplain beel was an economic as well as a social success for the fishing community involved in beel Mail following the first year of introducing CBFM. Gross fish production in project beel was about 4.7 times higher than that of control beel. In beel Mail the weight of harvested fishes were 6.17 and 3.5 times higher than the weight of fish fingerlings released in each hectare in beel Mail and beel Chandpur respectively. The less production of stocked fish in control beel was mainly due to less stocking of fish fingerlings, poor growth of fish and inappropriate management in fish culture. Another cause of less productivity of fish in control beel was the vast water area with poor embankment which was difficult to manage. Therefore large amount of fishes flew away to the connecting river when flood water increased in height. In addition, the beel was dried up by opening the sluice gate to remove the water for making the beel suitable for crop cultivation by the non participating land owners. This also hampered the optimum growth of the stocked fish in control beel. Thus it reveals that the lower production in control beel was due to inappropriate knowledge and training of the fish farmers about fish culture in these seasonal water bodies, funding constraint and also due to non supporting attitude of the other beneficiaries of the beel. But in project site, waterbody was well managed by the community. Open access of subsistence fishers were controlled. Fish culture was possible up to boro season, so the duration of fish culture was longer and growth of fish was optimum.

Farmers obtained TK $7481.23 \mathrm{ha}^{-1}$ as net return based on production cost in beel Mail and TK 3261.90 ha $^{-1}$ as net return based on production cost in Beel Chandpur. CBFM ensured sharing of benefits of fish culture among landowners and also landless fishermen by including more landless fishermen in the fishing community. In project site 52 fishermen were active participants of fishing community and they received 50\% of SIS and $20 \%$ of stocked fish as netting charge and share for being involved in the community. Where as in control site only 17 landless fishermen paid labor for fishing and received $14 \%$ of total harvested fish. Thus CBFM created more income opportunity for more landless fishermen during rainy season. CBFM approach in fish culture in this seasonally flooded beel generated a net income of Tk 7808 for each of 52 landless fishermen and Tk 21633 for each of 21 landowners. The average per capita fish consumption for poor landless fishermen also boost up by the implementation of CBFM. In addition, fund raising program for the fishermen society will make lower dependence of poor landless fishermen on money lenders. This approach in fish culture restricted the open access in beel and established social cohesion among the community members. Thus by the intervention of CBFM in management of open waterbody like beel Mail has got of a good 
start by raising overall productivity, fish consumption and making social progress in empowering poor landless fishermen. Fish culture or stocking of fish fingerlings in flooded rice field has been cited as an effective means of increasing farm productivity and for poverty alleviation [9-11]. Garaway et al. [12] reviewed that outcomes of stock enhancement in water body depends on the environments into which enhancements are introduced, involving dynamic interactions between the biological characteristics of the resource, the technical intervention of enhancement and, crucially, the people who use and manage it. Therefore active support, dedication and cooperation from local government institutions to the enduring development of the community, need to be ensured in order to carry on the progress achieved by the fishing community through CBFM practices in seasonal floodplain beel.

\section{Conclusion}

In the present study, it should that CBFM in the seasonal floodplain beel is socially acceptable and economically profitable. This approach benefits the landless poor fishermen by involving wide range of original fishermen in fish culture activities. Thus it ensures raise in household income and fish consumption. It helps in better sharing of benefits among the landowners and landless fishermen. It is expected that CBFM approach will be able to restrict exploitation of the poor original fishers by money lenders and other elite influential in these open water bodies by strengthening the bonding within fishermen society and by making them economically strong.

\section{Acknowledgements}

The authors would like to acknowledge the financial support for this research from the WorldFish Center and Malaysian Commonwealth Scholarship (MCS), Ministry of Higher Education, Malaysia.

\section{References}

1. F. Berkes, D. Feeny, B.J. McCay, and J. M. Acheson, Nature 340, 91 (1998). doi:10.1038/340091a0

2. E. Ostrom, Governing the Commons: The Evolution of Institutions for Collective Action (Cambridge University Press, Cambridge, MA. 1990).

3. R.S. Pomeroy and F. Berkes, Marine Policy 21 (5), 465 (1997). doi:10.1016/S0308-597X(97)00017-1

4. G. Hardin, Science 162, 1243 (1968). doi:10.1126/science.162.3859.1243

5. D. W. Bromley and M. M. Cernea, World Bank discussion paper 57 (World Bank, Washington, D.C., 1989).

6. F. Berkes, Property rights and costal fisheries- Community management and common property of costal fisheries in Asia and the Pacific: concepts, methods and experience, ICLARM conf. Proc. 45, ed. R. S. Pomeroy (1994) pp. 51-62.

7. P. M. Thompson, P. Sultana, M. N. Islam, M. M. Kabir, M. M. Hossain, and M. S. Kabir, Paper Presented at the International Workshop on Fisheries Co-management, Penang, Malaysia ( August 1999).

8. M. I. Hossain, Ph.D. Thesis, University Kebangsaan Malaysia, Selangore, Malaysia (2009). 
9. P. J. Dugan, M. M. Dey, and V. V. Sugunan, Agricultural Water Productivity 80, 262 (2006). doi:10.1016/j.agwat.2005.07.017

10. M. M. Dey, M. Prein, A. B. M. Mahfuzul Haque, Parvin Sultana, Nguyen Cong Dan, and Nguyen Van Hao, Aquaculture Economics and Management 9 (1-2), 65 (2005). doi:10.1080/13657300590961591

11. M. M. Dey and M. Prein, Participatory research at landscape level: floodprone ecosystems in Bangladesh and Vietnam: In Managing natural resources for sustainable livelihoods: uniting science and participation, Ed. B. Pound, S.S. Snapp, C. McDougall, and A. Braun (Earthscan and IDRC, London, 2003) p. 252.

12. C. J. Garaway, R. I. Arthur, B. Chamsingh, P. Homekingkeo, K. Lorenzen, B. Saengvilaikham, and K. Sidavong, Fisheries Research 80, 37 (2006). doi:10.1016/j.fishres.2006.03.012 